\title{
WIETNAM
}

Krzysztof Kutra

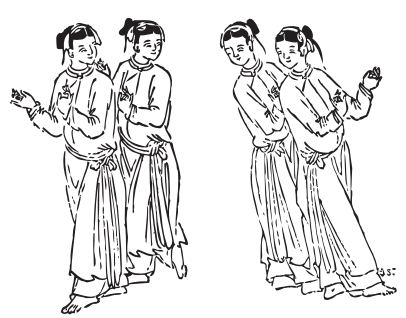

\section{CHIŃSKA REPUBLIKA LUDOWA WOBEC NIEPODLEGŁOŚCI I ZJEDNOCZENIA WIETNAMU. UWARUNKOWANIA WEWNĘTRZNE I MIĘDZYNARODOWE'}

W latach powojennych Półwysep Indochiński stał się jednym z ognisk zapalnych konfliktów międzynarodowych i terenem ścierania się wpływów mocarstw. Walka o uznanie niepodległości Wietnamu i wyrwanie terytorium kraju spod kurateli kolonialnej dała początek zaangażowaniu w konflikt Stanów Zjednoczonych i Związku Socjalistycznych Republik Radzieckich. Czynnikiem podstawowym dla rozwoju sytuacji stał się sojusz z Chińską Republiką Ludową, którego kształt był odbiciem polityki wewnętrznej i międzynarodowej ChRL oraz kształtowania się pozycji i tożsamości nowego mocarstwa w latach powojennych. Walcząca strona wietnamska starała się w jak największym stopniu wykorzystać przychylność północnego sąsiada, jak również jego konflikty regionalne i rywalizację mocarstwową do budowy niepodległości państwa i podwyższenia jego znaczenia w regionie.

\section{Konferencja genewska i rola Chińskiej Republiki Ludowej}

Pierwszy konflikt indochiński, toczący się od 1946 r. między Francją a Demokratyczną Republiką Wietnamu, przyniósł klęskę Francuzom. Została ona przypieczętowana podczas międzynarodowej konferencji, która rozpoczęła się w Genewie 8 maja 1954 r., a zakończyła podpisaniem 20 i 21 lipca układów pokojowych.

\footnotetext{
${ }^{1}$ Praca przygotowana pod kierunkiem prof. dr. hab. Jana Rowińskiego.
} 
Zakładały one podział terytorium na dwa państwa: DRW i Wietnam Południowy ${ }^{2}$, które miały pozostać neutralne, bez prawa zawierania sojuszy o charakterze militarnym. Linia demarkacyjna miała przebiegać wzdłuż rzeki Ben Hai, co odpowiada w przybliżeniu 17. równoleżnikowi. Wybory, które zadecydowałyby o przyszłym statusie obu państw, miały się odbyć w lipcu 1956 r., pod nadzorem polsko-indyjsko-kanadyjskiej komisji. Porozumienia zakładały też zawieszenie broni w Laosie i Kambodży oraz wycofanie oddziałów Viet Minhu z terytorium tych państw. Wojska francuskie miały opuścić obszar wszystkich trzech państw Półwyspu Indochińskiego.

Podpisanie postanowień genewskich było sukcesem dyplomacji ZSRR, a w jeszcze większym stopniu ChRL. Dzięki umiejętnej polityce premiera Zhou Enlaia ChRL zrealizowała wszystkie zamierzone cele. Pochodną tego było przerwanie izolacji państwa oraz nawiązanie dialogu z Francją i Wielką Brytanią. Pekin wzmocnił też swoją pozycję wśród państw Azji i Afryki, odwołując się do ideologii antyimperialistycznej i antykolonialnej. Postanowienia konferencji genewskiej okazały się jednak swoistym zawieszeniem broni, a nie początkiem trwałego procesu pokojowego. Decydujące dla ich niepowodzenia były różnice interesów mocarstw, które wpłynęły na brak woli implementacji postanowień. Państwa sygnatariusze porozumień genewskich nie starały się o przestrzeganie umów, gdy ich treść znalazła się w kolizji z ich interesem.

ChRL, która była wielkim wygranym konferencji, także nie stała się orędownikiem przestrzegania jej zapisów. Chińczycy wierzyli, że istniała możliwość pokojowego zjednoczenia Wietnamu, a jeśli to by się nie powiodło, to należało szukać innych rozwiązań, aczkolwiek w $1954 \mathrm{r}$. nie można było sobie pozwolić na eskalację konfliktu. Istota tego podejścia polegała na tym, że rozwiązanie konfliktu indochińskiego nie może się odbywać bez udziału ChRL, a tym bardziej wbrew jej interesom. Administracja prezydenta Dwighta Davida Eisenhowera, wykorzystując podział Wietnamu, umocniła swoją obecność w regionie ${ }^{3}$. Interwencja amerykańska, której kierownictwo Komunistycznej Partii Chin (KPCh) tak bardzo się obawiało, została jedynie odłożona w czasie.

2 Podczas negocjacji strona chińska po raz pierwszy odniosła się do Wietnamu Południowego, uznając tym samym istnienie tego państwa.

3 Przyczyniło sie do tego zawarcie przez Stany Zjednoczone, Francję, Wielką Brytanię, Nową Zelandię, Australię, Pakistan, Filipiny i Tajlandię 8 września 1954 r. w Manili Paktu Azji Południowo-Wschodniej (SEATO). Szerzej patrz: Piotr Ostaszewski, Wietnam. Najdtuższy konflikt powojennego świata 1945-1975, Warszawa 2000, s. 294. 


\section{Od pokojowego współistnienia do rywalizacii w regionie}

Pryncypiami polityki ChRL po konferencji genewskiej było dalsze zbliżenie z ZSRR i opozycja wobec imperializmu poprzez budowanie pokojowych więzi z państwami regionu. Celem nadrzędnym było wówczas zapewnienie korzystnych warunków do obudowania gospodarki państwa. W sferze wewnętrznej miała temu służyć rozpoczęta w 1953 r. realizacja pierwszego planu pięcioletniego, a w sferze stosunków międzynarodowych - promowanie pięciu zasad pokojowego współistnienia. Deklaracja Mao Zedonga o niewspieraniu ruchów rewolucyjnych w Laosie, Kambodży, Birmie, Tajlandii i Malajach formalnie miała być realizacją zasady nieingerencji w wewnętrzne sprawy innych państw ${ }^{4}$. Deklarując w ten sposób odejście od polityki eksportu rewolucji, ChRL starała się o rozszerzenie swoich wpływów poprzez uznanie rządów państw azjatyckich i promowanie pokojowego współistnienia. Chiny odegrały wiodącą rolę na konferencji w Bandungu (1824 kwietnia 1955), która dała początek skutecznemu otwarciu dyplomatycznemu wobec państw Azji, Bliskiego Wschodu i Afryki. Mao Zedong deklarował publicznie, że możliwe jest pokojowe współistnienie państw o odmiennych systemach politycznych. W sierpniu 1955 r. rozpoczęły się chińsko-amerykańskie rozmowy na szczeblu ambasadorów.

Powstanie SEATO, które było wymierzone w ChRL i DRW oraz zachwiało neutralnością Laosu, Kambodży i Wietnamu Południowego, początkowo nie skłoniło Mao do zmiany dotychczasowej polityki. Taktyka przewodniczącego była podyktowana doraźnymi potrzebami politycznymi, wśród których na pierwszy plan wysunęło się zapewnienie korzystnego klimatu do rozwoju wewnętrznego ChRL. Jednakże kierunek przyjęty w 1953 r. nie stanowił logicznego rozwoju doktryny komunistycznej Mao Zedonga. Wraz ze zmianą sytuacji międzynarodowej w końcu lat 50. XX w. ideologia rewolucyjna ponownie zaczęla odgrywać dominującą rolę w polityce wewnętrznej i zagranicznej ChRL.

W owym czasie również rząd DRW był zaabsorbowany problemami wewnętrznymi, z których najważniejszymi były reforma rolna oraz restrukturyzacja przemysłu. Wobec występowania dotkliwych braków żywnościowych zacieśniano współpracę handlową z państwami komunistycznymi. Głównym partnerem handlowym DRW była ChRL, z którą w 1955 r. zawarto umowę handlową, a także - podczas

${ }^{4}$ Yang Kuisong, Changes in Mao Zedong's Attitude toward the Indochina War, 1949-1973, Cold War International History Project, Woodrow Wilson International Center for Scholars, http:// wwics.si.edu/index.cfm?topic_id=1409\&fuseaction=library.document\&id=952 (wejście: 3.12 .2004 ).

Deklaracja była przedstawiona na jednym z posiedzeń najwyższego kierownictwa i nieujawniona oficjalnie. 
oficjalnej wizyty Ho Chi Minha w Pekinie - podpisano traktaty przyjaźni, poparte udzieleniem sojusznikowi pożyczki w wysokości 200 mln USD, którą następnie powiększono o sumę $160 \mathrm{mln}$ USD.

Rząd DRW pragnął przed wyzwoleniem Południa przede wszystkim umocnić socjalizm w kraju i dokonać niezbędnych reform. Skupienie uwagi na sprawach wewnętrznych było zbieżne z interesami ChRL. Jednocześnie niemożność wprowadzenia w życie postanowień genewskich i rozwiązania pokojowymi środkami napięć w Indochinach stawała się coraz bardziej oczywista. 6 czerwca 1955 r. minister spraw zagranicznych DRW Pham Van Dong w przesłanej do Sajgonu depeszy oznajmił gotowość Hanoi do rozpoczęcia przygotowań wyborczych. W odpowiedzi gen. Ngo Dinh Diem oświadczył, że rząd Republiki Wietnamu nie podpisał postanowień genewskich i nie jest nimi związany. Podał też w wątpliwość możliwość przeprowadzenia na Północy wolnych wyborów i wyraził nadzieję, że rząd narodowy przyniesie wolność rodakom mieszkającym na północ od 17. równoleżnika ${ }^{5}$ W zaistniałej sytuacji brak poparcia Moskwy i Pekinu nie pozwalał jeszcze DRW na podjęcie próby zbrojnego zjednoczenia kraju ${ }^{6}$.

Chociaż ChRL otwarcie nie negowała znaczenia doktryny pokojowego współistnienia, wkrótce dały się zauważyć istotne różnice w sposobie postrzegania rozwoju socjalizmu między Nikitą Chruszczowem a Mao Zedongiem. W październiku 1957 r. na moskiewskiej konferencji partii komunistycznych zwołanej z okazji 40. rocznicy rewolucji październikowej Mao podkreślał znaczenie walki klas i rewolucji. Kryzys węgierski 1956 r. i rozpętana kampania walki z elementami prawicowymi w Chinach (1957 r.) unaoczniły Mao potrzebę ponownego odwołania się do mas $\mathrm{w}$ walce $\mathrm{z}$ oponentami politycznymi oraz położenia większego nacisku na permanentną rewolucję jako drogę rozwoju.

Kryzys w Cieśninie Tajwańskiej w 1958 r. i zawarcie porozumienia obronnego między Republiką Chińską na Tajwanie a Stanami Zjednoczonymi, wzmocnienie polityki USA w ramach SEATO oraz spór graniczny i rosnąca liczba zbrojnych incydentów między ChRL a Indiami ujawniły trudności i brak woli pokojowego rozwiązania problemów międzynarodowych Chin. Coraz wyraźniej zaznaczał się stan rywalizacji o wpływy w Azji Wschodniej. W końcu lat 50. oprócz rozbieżności na tle ideologicznym pojawiły się realne symptomy kryzysu sojuszu mocarstw

${ }^{5}$ P. Ostaszewski, op.cit., s. 325.

${ }^{6}$ Stanowisko ZSRR było wówczas zbieżne z dotychczasową polityką ChRL. Podczas XX Zjazdu KPZR Nikita Chruszczow potwierdził zasadę pokojowego współistnienia jako fundamentu radzieckiej polityki zagranicznej oraz podkreślił, że istnieją różne drogi dojścia do socjalizmu, m.in. przez pokojowy rozwój. W styczniu $1957 \mathrm{r}$. Chruszczow zaproponował przyjęcie obu państw wietnamskich do ONZ. 
komunistycznych ${ }^{7}$. Mao Zedong twierdził jednak, że istniejące napięcia, choć mają aspekty negatywne, służą mobilizacji mas w walce rewolucyjnej, podczas gdy Nikita Chruszczow konsekwentnie promował ideę pokojowego współistnienia.

Ho Chi Minh wziął udział w XXI Zjeździe KPZR, a w lipcu i sierpniu 1959 r. prowadził rozmowy w Moskwie i Pekinie, przekonując o potrzebie wsparcia dla walki zbrojnej w Wietnamie Południowym oraz podejmując próby mediacji między przywódcami mocarstw komunistycznych. Zwrot, jaki nastąpił w polityce chińskiej, był niewątpliwie korzystny dla DRW, jednak nie oznaczał natychmiastowego i otwartego poparcia ruchów narodowo-wyzwoleńczych w Indochinach.

$\mathrm{Na}$ XV Plenum Partii Pracujących Wietnamu (PPW) przyjęto rezolucję deklarującą podjęcie ofensywy zbrojnej w celu obalenia rządu Ngo Dinh Diema. Vietcong $^{8}$ penetrował terytorium Laosu, swobodnie przekraczając granicę. DRW, pragnąc zachować jak największe wpływy w Laosie, udzielała wsparcia tamtejszym komunistom, czego wyrazem była wciąż rosnąca skala przerzutu broni i amunicji szlakiem granicznym - tzw. ścieżką Ho Chi Minha. ChRL zajmowała wówczas dosyć ostrożne stanowisko w kwestii Laosu i konfliktu w Wietnamie. Z pewnością dominacja Hanoi w Laosie i Kambodży nie podobała się Pekinowi. Ponadto wobec obecności obserwatorów ONZ w Laosie Chińczycy chcieli uniknąć wrażenia, jakoby otwarcie wspierali tam ruchy rewolucyjne. Różnice w interesach i skali powiązań międzynarodowych między ChRL i DRW oraz realizowana przez Amerykanów „doktryna powstrzymywania” kazały zachować Mao większą ostrożność. ChRL radziła Pathet Lao przyjęcie długofalowej strategii oraz rozwijanie walki podziemnej. Podobne stanowisko kierownictwo KPCh zajęło wobec decyzji PPW o wznowieniu walki zbrojnej na Południu. Mao w rozmowach z Ho Chi Minhem radził wzmacniać się politycznie, prowadzić infiltrację i przygotowywać warunki do przyszłej konfrontacji z imperialistami9.

Koniec lat 50. XX w. przyniósł nasilenie sporu chińsko-radzieckiego. Mao odrzucił publicznie zasadę pokojowej koegzystencji, wskazując, że nie jest ona możliwa między krajami imperialistycznymi a komunistycznymi. Jako że burżuazja używała wojny dla zastraszenia mas, partia (KPCh) była zmuszona promować pokojową

${ }^{7}$ W 1958 r. Mao, planując zbombardowanie znajdującej się obok portu Xiamen wyspy Quemoy, na której stacjonowały wojska guomindangowskie, nie powiadomił ZSRR, co przy możliwości eskalacji konfliktu było poważnym uchybieniem w zobowiązaniach sojuszniczych. Sowieci odmówili poparcia ChRL, a następnie nie wywiązali się z obietnicy dostarczenia broni nuklearnej.

${ }^{8}$ Nazwa używana ówcześnie na Zachodzie na określenie wietnamskiej partyzantki komunistycznej. Redakcja.

920 grudnia 1960 r., zgodnie z ustaleniami III Zjazdu PPW, powołano Front Wyzwolenia Narodowego Wietnamu Południowego. Było to trafne propagandowo posunięcie, gdyż Front formalnie stanowił niezależny od DRW ruch wyzwoleńczy, reprezentujący wolę narodu wietnamskiego na Południu. 
egzystencję, aby zdobyć zaufanie ludu ${ }^{10}$. Wyrazem nowego kierunku w polityce wewnętrznej były zapoczątkowane w 1957 r. represje wobec inteligencji, a następnie ogromny wysiłek społeczny związany z „wielkim skokiem” (1958-1960). Radykalizacja polityki ChRL była w istocie wyborem stalinowskiego wariantu budowy mocarstwowej pozycji kraju przez wspieranie ruchów narodowowyzwoleńczych w Trzecim Świecie. Konsekwencją konfliktu ideologicznego z ZSRR była krytyka poczynań PPW. Mao Zedong i Zhou Enlai popierali DRW w walce z imperializmem, lecz odnosili się krytycznie do jej zbliżenia ze Związkiem Radzieckim i zejścia z drogi wytyczonej przez rewolucję chińską, zwłaszcza niedokończenia reformy rolnej i zbyt biernego stosunku do rewolucji światowej.

Podczas spotkania Ho Chi Minha i Mao Zedonga w listopadzie 1960 r. Mao wyraził uznanie dla podjęcia walki zbrojnej w Wietnamie Południowym i Laosie. Różnice ujawniły się w podejściu do rządów „reakcyjnych”, co do których chiński przywódca prezentował bardziej bezkompromisowe stanowisko.

\section{Wojna o zjednoczenie Wietnamu i krucha równowaga sojuszy w obozie komunistycznym}

$\mathrm{Z}$ początkiem lat $60 . \mathrm{XX}$ w. perspektywa zaangażowania ChRL w konflikt w Wietnamie i Laosie podzieliła chińskie kierownictwo. Sekretarz generalny KC KPCh, wicepremier Deng Xiaoping, postulował prowadzenie operacji partyzanckich na niewielką skalę, aby nie prowokować Amerykanów. Wiceprzewodniczący KC KPCh, premier Zhou Enlai, wyszczególnił trzy możliwości rozwoju działań wojennych: 1) wojna partyzancka na małą skalę, 2) szersze działania wojenne obejmujące terytorium Laosu i Wietnamu Południowego, 3) wielka wojna z udziałem armii Stanów Zjednoczonych. Sam proponował przyjęcie drugiego scenariusza. Natomiast przewodniczący Komisji Wojskowej KPCh i Komisji Wojskowej ChRL Mao Zedong, którego głos miał największą wagę, stał na stanowisku, że wielka wojna jest nieunikniona, że DRW powinna - wspierając militarnie rewolucję w Laosie - deklarować publicznie, że jej wojska nie są zaangażowane w tym kraju. Z tym scenariuszem wiązały się obietnice Mao o pomocy w zaopatrzeniu dla armii wietnamskiej i laotańskiej za pośrednictwem DRW.

Na początku lat 60. XX w. nieudana próba transformacji społecznej, jaką stanowił „wielki skok” i związane z nim represje, mocno zachwiały autorytetem Mao Zedonga. Różnice w podejściu do kryzysu wietnamskiego udowodniły, że chińskie kierownictwo nie mówi już jednym głosem. Mao zdawał sobie sprawę, że za-

${ }^{10}$ Yang Kuisong, op.cit. (wejście: 13.01.2005). 
angażowanie w pomoc DRW stworzy perspektywę zagrożenia ChRL amerykańskim imperializmem, która zmobilizuje siły rewolucyjne do walki wewnątrz kraju, a jemu da szansę rozprawienia się z rewizjonizmem w $\mathrm{KPCh}^{11}$.

Na tle chińsko-radzieckiego konfliktu o przywództwo w komunistycznym świecie kwestie ideologiczne znalazły się również w centrum relacji ChRL-DRW. Liu Shaoqi krytykował próby mediacji Ho Chi Minha w stosunkach chińsko-radzieckich, zarzucając mu sprzyjanie Moskwie ${ }^{12}$. W tym konflikcie ChRL chciała mieć DRW po swojej stronie - stąd rosnąca presja na Wietnamczyków, aby dokonali rewizji dotychczasowego kursu i jednoznacznie wsparli ChRL przeciwko ZSRR. Mao nie tolerował też zbytniej odrębności ustrojowo-ideologicznej południowego sąsiada, odnosząc się z jeszcze bardziej negatywnie niż jego zastępca do wietnamskich prób mediacji między dwoma wielkimi państwami komunistycznymi ${ }^{13}$. Obok wysiłków na rzecz ideologicznego przekształcenia PPW na wzór KPCh (mimo związanych z tym kontrowersji) Pekin zaczął radykalnie wspierać wojnę w Wietnamie Południowym. Nie będąc już tak bezpośrednio zaangażowana w planowanie operacji, jak w latach 1953-1954, ChRL stworzyła dla DRW zaplecze finansowo-materiałowe, niezbędne do prowadzenia wojny.

Wiosną 1963 r. nastąpiła eskalacja konfliktów wewnętrznych w Wietnamie Południowym. Ekipa Ngo, nie mając zaplecza w postaci sojuszników politycznych i czując brak poparcia amerykańskiego, zwróciła się w stronę negocjacji z DRW na temat ewentualnego zjednoczenia ${ }^{14}$. Premier Pham Van Dong stawiał jeden warunek: pozbycie się Amerykanów z Wietnamu. Nie jest do końca znane chińskie stanowisko wobec tego projektu. Prawdopodobnie zjednoczenie pod przywództwem DRW i zdecydowane ograniczenie pola działania Amerykanom byłoby dla ChRL korzystne, mimo znacznego wzmocnienia pozycji DRW w bloku komuni-

11 Promowanie rewolucji w kraju, jak i za granicą było dla Mao środkiem stwarzającym przychylne warunki do wzmocnienia jego pozycji w partii. Hasła walki z rewizjonizmem były zapowiedzią czystek rewolucji kulturalnej.

12 Yang Kuisong, op.cit. (wejście: 16.01.2005).

13 Na IX Plenum PPW, wobec regresu w działaniach zbrojnych na Południu, przywódcy wietnamscy musieli zmodyfikować strategię, odchodząc od trójfazowej strategii „wojny ludowej” Mao Zedonga. Sytuacja w Wietnamie Południowym wymagała elastycznego podejścia i rozłożenia w czasie całej wojny. Decydujący wpływ miały odmienne od tych z 1954 r. warunki prowadzenia operacji wojskowych. W 1963 r. nie było tak silnego zaplecza wśród ludności wiejskiej, która wielokrotnie zmuszana siłą do współpracy z władzą nie miała już potrzebnego wojennego entuzjazmu. Ponadto w Wietnamie Południowym istniał rząd, który, mimo wszystkich wad i zależności od USA, nie był postrzegany jako obca władza kolonialna.

${ }_{14}$ Polityka Ngo Dinh Diema była dużym problemem zarówno dla administracji prezydenta Eisenhowera, jak i Kennedy’ego. Brak reform, niedopuszczanie wolności politycznych oraz ogólnie autorytarny styl rządzenia tworzyły negatywny obraz sojusznika w amerykańskich mediach, przez co amerykańska opinia publiczna stawała się coraz bardziej niechętna polityce Waszyngtonu. 
stycznym. Jednakże wypadki potoczyły się w innym kierunku. 1 listopada $1963 \mathrm{r}$. dokonał się w Wietnamie Południowym zamach stanu. Zapowiedziano rozliczenie się z pozostałościami reżimu Ngo Dinh Diema i ogłoszenie powszechnej amnestii z wyjątkiem osób oskarżonych o komunizm. Ułatwiło to sytuację Stanom Zjednoczonym. Jednakże kiedy nowy - po śmierci Johna F. Kennedy'ego - prezydent USA Lyndon Johnson stanął przed problemem ogromnego zaangażowania politycznego i ekonomicznego w Wietnamie, nie miał on jasnej koncepcji roli Stanów Zjednoczonych w konflikcie.

Ho Chi Minh wciąż liczył na chińsko-radzieckie porozumienie, co umożliwiłoby utrzymanie dwóch równorzędnych źródeł pomocy materiałowo-finansowej. Gdy jednak Nikita Chruszczow zapowiedział, że ZSRR nie będzie wspierał wojny w Wietnamie, stało się jasne, że głównym sojusznikiem Wietnamczyków pozostanie ChRL. W rozmowie z Mao sekretarz generalny PPW Le Duan wyraził swoje rozczarowanie postawą radziecką. W odpowiedzi Mao zapewnił go o poparciu Chin dla DRW, stojacej na pierwszej linii frontu walki rewolucyjnej. Dodat, że DRW ponosiła ogromną odpowiedzialność, budując socjalizm w kraju i jednocześnie wspierając walkę zbrojną w Wietnamie Południowym i Laosie. Jako że DRW poświęcała życie swoich żołnierzy, ChRL była gotowa zobowiązać się wobec niej do zaopatrzenia militarnego, materiałowego oraz wsparcia logistyczne$\mathrm{go}^{15}$. Takie stanowisko Mao było zarówno podsumowaniem ówczesnej sytuacji, jak i zapowiedzią rozwoju współpracy. Pomoc DRW była elementem międzynarodowego zaangażowania ChRL na rzecz rewolucji. Na początku lat 60 . XX w. rozpoczęto wysyłanie misji doradczych i militarnych do krajów Azji, Afryki i Ameryki Łacińskiej. Mao chętnie spotykał się z przedstawicielami partii komunistycznych, zachęcając ich do podjęcia konfrontacji militarnej i dzieląc się doświadczeniami chińskiej rewolucji. Jednocześnie, krytykował postawę ChRL na konferencji genewskiej i w drugiej połowie lat 50. XX w.: ówczesną politykę Chin wobec Wietnamu - zaniechanie walki i ograniczenie jej skali - uznał za błąd, który kosztował życie 160 tys. Wietnamczyków z Południa.

Stanowisko ChRL pozostawało w opozycji do polityki ZSRR, z którym spór ideologiczny przerodził się $\mathrm{w}$ długotrwały antagonizm. Nastawiony koncyliacyjnie wobec Zachodu rząd ZSRR nie mógł wówczas poprzeć walki DRW z dwóch podstawowych względów. Po pierwsze, po wygaśnięciu kryzysu kubańskiego rząd Chruszczowa obawiał się bezpośredniej konfrontacji ze Stanami Zjednoczonymi. Po drugie, pomoc dla DRW byłaby wsparciem polityki prowadzonej przez rywalizującą ChRL, która mogłaby wyciągnąc z konfliktu wietnamskiego duże korzyści, rozszerzając swoje strefy wpływów oraz odnosząc ogromny sukces propagandowy.

${ }^{15}$ Yang Kuisong, op.cit. (wejście: 19.01.2005). 
Podczas wizyty w Moskwie w lutym 1964 r. Le Duan odniósł się krytycznie do ugodowej postawy radzieckiej wobec Zachodu, niewspierania ruchów wyzwoleńczych i popierania Indii w chińsko-indyjskim konflikcie granicznym. Zajęcie takiego stanowiska pogłębiło jedynie impas w stosunkach DRW z ZSRR.

Mao był bardzo zadowolony ze wsparcia, jakiego udzielała mu PPW. Jednocześnie podkreślał konieczność dobrej organizacji wewnętrznej partii, która miała być gwarantem siły państwa. Akcentował potrzebę zaangażowania mas i rozprawienia się z tendencjami rewizjonistycznymi. W 1963 r. chińscy i wietnamscy przywódcy wojskowi rozpoczęli rozmowy na temat przygotowania do obrony przed spodziewaną interwencją amerykańską w Wietnamie. Mao podkreślał potrzebę przejęcia inicjatywy na polu walki dla uzyskania dogodnej pozycji do ewentualnych negocjacji ${ }^{16}$. Uspokajał też Wietnamczyków, by nie obawiali się interwencji amerykańskiej, gdyż Chińska Armia Ludowo-Wyzwoleńcza, jak twierdził, była gotowa wkroczyć na terytorium Wietnamu i w najgorszym wypadku konflikt mógł się rozwinąć w kierunku sytuacji analogicznej do wojny koreańskiej. Przywódca chiński tradycyjnie już akcentował znaczenie wyzwolenia Laosu dla rozwoju sytuacji w Wietnamie. Mao proponował wyszkolenie 3-4 tys. żołnierzy i przerzucenie ich na terytorium Laosu w celu zdobycia przewagi na terenach, które miały stanowić zaplecze dla działań Vietcongu.

Do maja 1964 r. wzrosła liczba obszarów kontrolowanych przez komunistów wietnamskich. Usprawniono sieć transportową, dzięki czemu nasiliła się infiltracja Wietnamu Południowego. W drugiej połowie roku Vietcong kontrolował połowę terytorium kraju. 17 czerwca prezydent Johnson ostrzegł premiera Pham Van Donga, że Stany Zjednoczone będą gotowe wywrzeć na DRW ogromną presję militarną w celu ograniczenia wsparcia udzielanego Vietcongowi. W lipcu tegoż roku w Hanoi miało miejsce spotkanie delegacji ChRL, DRW i Pathet Lao w celu analizy sytuacji w Wietnamie Południowym i Laosie. Chociaż treść rozmów nie jest dokładnie znana, wiadomo, że przywódcy trzech partii komunistycznych ustalali warunki współpracy wobec rosnącej groźby interwencji amerykańskiej ${ }^{17}$.

W sierpniu 1964 r., po incydentach zbrojnych między jednostkami amerykańskimi i północnowietnamskimi w Zatoce Tonkińskiej, Zhou Enlai poprosił Ho Chi Minha o analizę sytuacji, opracowanie planu działań odwetowych oraz zarządzenie mobilizacji wojennej. Także Pekin postawił w stan gotowości lotnictwo i marynarkę wojenną w przygranicznych okręgach wojskowych Kunming i Guangzhou.

${ }^{16}$ Nawiązywał w tym do taktyki przyjętej podczas pierwszej wojny indochińskiej wobec Francuzów, a forsowanej wcześniej przez ChRL w Korei.

${ }_{17}$ Qiang Zhai, Beijing and the Vietnam Conflict, 1964-1965: New Chinese Evidence, Cold War International History Project, Woodrow Wilson International Center for Scholars, http://wwics.si.edu/ index.cfm?topic_id=1409\&fuseaction=library.document\&id=244 (wejście: 26.01 .2005 ). 
W Chinach doszło do masowych antyamerykańskich demonstracji solidarności ze społeczeństwem wietnamskim, w których brało udział ok. 20 mln ludzi.

W sierpniu ChRL przekazała DRW piętnaście myśliwców MIG-15 i MIG-17, zgodziła się przeprowadzić trening wietnamskich pilotów i rozpoczęła budowę baz lotniczych wzdłuż granicy z Wietnamem. W grudniu ChRL i DRW podpisały umowę wojskową, na mocy której Chiny miały skierować do Wietnamu Południowego 300 tys. żołnierzy i tym samym umożliwić DRW przerzut własnych sił na Południe w celu wsparcia operacji Vietcongu.

Chaos na południowowietnamskiej scenie politycznej jesienią 1964 r. sprzyjał planom operacyjnym Vietcongu. Korzystna dla wizerunku DRW okazała się również sytuacja międzynarodowa. Odrzucenie przez administrację amerykańską zgłoszonej w październiku przez sekretarza generalnego ONZ U Thanta propozycji wstępnych negocjacji pokojowych w stolicy Birmy Rangunie ${ }^{18}$ stworzyło obraz koncyliacyjnie nastawionego rządu północnowietnamskiego i konfrontacyjnej administracji amerykańskiej ${ }^{19}$. Jednym z powodów, dla których DRW wyraziła chęć rozmów pokojowych, było stanowisko rządu ZSRR, który był skłonny pośredniczyć w rokowaniach. W ZSRR zachodziły wówczas istotne zmiany polityczne, za sprawą których wojna wietnamska miała nabrać znaczenia priorytetu $\mathrm{w}$ radzieckiej polityce zagranicznej.

W październiku 1964 r. sekretarzem generalnym KPZR został Leonid Breżniew, który nie zamierzał kontynuować ostrożnej polityki zagranicznej, charakterystycznej dla ostatnich lat kadencji Chruszczowa, a był bardziej zorientowany na rozszerzenie radzieckich wpływów na świecie. Pod koniec miesiąca odbyło się w Moskwie spotkanie premiera Pham Van Donga z Breżniewem i premierem Aleksiejem Kosyginem, podczas którego rząd ZSRR zaproponował materiałową i finansową pomoc dla DRW. Odtąd krytyczne stanowisko rządu północnowietnamskiego ustąpiło miejsca deklaracjom przyjaźni i wzajemnego poparcia.

${ }^{18}$ Chińczycy od początku odnosili się sceptycznie do rokowań DRW z USA. W rozmowie z Pham Van Dongiem 5 października 1964 r. w Pekinie Mao Zedong podkreślił potrzebę układania się z Amerykanami z pozycji siły, podając przykład rozmów chińsko-amerykańskich w sprawie Tajwanu oraz rokowań francusko-wietnamskich w czasie pierwszej wojny indochińskiej, http://wwics.si.edu/index.cfm?topic_id=1409\&fuseaction=library.document\&id=83 (wejście: 7.02.2005).

19 Z czasem umacniało się twarde stanowisko DRW w kwestii rokowań z Amerykanami. W myśl zasady, że negocjacje należy podejmować z pozycji siły, rząd DRW stawiał twarde warunki (natychmiastowe zaprzestanie działań wojennych i wycofanie wojsk amerykańskich z terytorium obydwu państw wietnamskich), podczas gdy czas działał zdecydowanie na korzyść strony wietnamskiej wiązało się to z rosnącym niezadowoleniem opinii publicznej w USA i brakiem wymiernych skutków wojny (nie udało się zmusić DRW do zaprzestania pomocy Vietcongowi). 
Rewizyta szefa rządu radzieckiego nastąpiła w lutym $1965 \mathrm{r}^{20}{ }^{20} \mathrm{~W}$ drodze do Hanoi premier Kosygin zatrzymał się w Pekinie, chcąc przekonać przywódców ChRL do zjednoczenia wysiłków na rzecz zjednoczenia Wietnamu. Chodziło m.in. o szersze udostępnienie terytorium Chin dla transportów z ZSRR. Chociaż rząd ChRL odnosił się nieufnie do planów radzieckich, widząc w nich chęć odebrania mu wpływów w wietnamskim ruchu komunistycznym, to brak zgody na współpracę z ZSRR przy zaopatrzeniu DRW stawiałby pod znakiem zapytania rzeczywiste intencje Chin w stosunku do południowego sąsiada. Ostatecznie ChRL zgodziła się na radzieckie transporty przez swoje terytorium, utrudniając jednak możliwie efektywne wykonanie misji ${ }^{21}$.

Strona wietnamska zdawała sobie sprawę, że Moskwa dąży głównie do rozprzestrzenienia swoich wpływów w regionie kosztem osłabienia pozycji ChRL. Pomoc radziecka miała jednak wówczas dla DRW pierwszorzędne znaczenie, zwłaszcza że ChRL nie była w stanie dostarczyć sprzętu do obrony przeciwlotniczej na odpowiednią skalę. Ponadto uruchomienie drugiego źródła pomocy ekonomicznej było wielce pożądane wobec trudności gospodarczych Wietnamu i miało skłonić ChRL do bardziej zdecydowanego działania.

Tymczasem 2 lutego 1965 r., w odpowiedzi na wcześniejsze ataki Vietcongu na bazy amerykańskie, Siły Powietrzne USA przeprowadziły naloty na koszary w północnowietnamskiej strefie przygranicznej, w pobliżu miejscowości Dong Hoi. Rozpoczęcie operacji „Rolling Thunder” oraz wysłanie do Wietnamu Południowego kolejnych oddziałów skłoniło Pekin do sformułowania na wiosnę 1965 r. trzech podstawowych zasad strategii chińskiej. Po pierwsze, jeśli Amerykanie użyliby sił lądowych do ataku na DRW, ChRL miała wysłać na Południe swoje wojska. Po drugie, Chiny miały przekazać Stanom Zjednoczonym wyraźne ostrzeżenie, powstrzymujące je przed nieograniczonym rozszerzaniem ekspansji militarnej. Po trzecie, ChRL miała dążyć do unikania konfrontacji ze Stanami Zjednoczonymi tak długo, jak to możliwe, jednakże nie wykluczając jej, jeżeli okaże się konieczna $^{22}$. Przygotowując się na najgorsze, KC KPCh wydał 12 lipca 1965 r. „Instruk-

${ }^{20}$ Popierając DRW w wojnie z USA, przywódcy ZSRR liczyli na uwikłanie wroga w konflikt indochiński i osłabienie amerykańskiej zdolności do obrony i realizacji swoich interesów w innych częściach świata. Wprowadzając politykę zagraniczną na nowe tory, Breżniew działał bez obciążenia porażką ZSRR w konflikcie kubańskim, który określił ostatnie lata działalności Nikity Chruszczowa.

${ }^{21}$ Podczas rozmów między Zhou Enlaiem a Ho Chi Minhem 1 marca 1965 r. w Hanoi Zhou ostrzegał Ho przed współpracą z Rosjanami, wskazując koniunkturalizm radzieckiego zaangażowania w Korei, ChRL oraz na Kubie. Zhou Enlai and Ho Chi Minh; Hanoi, 1 March 1965, Cold War International History Project, Woodrow Wilson International Center for Scholars, http://wwics.si.edu/ index.cfm?topic_id=1409\&fuseaction=library.document\&id=378 (wejście: 8.02 .2005 ).

${ }^{22}$ Chen Jian, China's Involvement in the Vietnam War, 1964-69, „The China Quarterly”, June 1995, No. 142, s. 355-387. 
cje dla wzmocnienia przygotowań do przyszłych wojen", które stały się jednym z najważniejszych dokumentów życia społeczno-politycznego w ChRL w latach 60. XX w. Zwracały uwagę na eskalację agresji przez Stany Zjednoczone i stawiały partię, armię i całe społeczeństwo w stan podwyższonej gotowości bojowej. Apelowano o mobilizację całego potencjału Chin w obliczu możliwej walki u boku DRW, co stanowiło jednocześnie odbicie dążeń Mao Zedonga do wzniecenia wewnętrznej rewolucji, odsunięcia oponentów w kierownictwie partii i ponownego przejęcia władzy w państwie.

Liczne kontakty chińsko-wietnamskie na najwyższym szczeblu w 1965 r. świadczyły o dobrej współpracy ChRL i DRW. Podczas rozmów Le Duana i Vo Nguyen Giapa z Liu Shaoqi 8 kwietnia w Pekinie uzyskano obietnicę wysłania do DRW chińskich ochotników pilotów, oficerów wojsk naziemnych oraz jednostek inżynieryjno-saperskich do budowy dróg i mostów łączących terytoria obu państw ${ }^{23}$. Siły chińskie miały zapewnić obronę przeciwlotniczą zarówno Hanoi oraz prowincji północnych, jak i szlaków komunikacyjnych.

Podczas tajnych spotkań Ho Chi Minha z Mao Zedongiem w Changsha, stolicy prowincji Hunan, opracowano wspólny plan działania na wypadek eskalacji inwazji amerykańskiej. Mao wyraził też zgodę na dostarczenie Wietnamczykom materiałów do budowy kolejnych (tym razem dwunastu) szlaków przerzutowych. W lecie z inicjatywy premiera Zhou Enlaia powołano do życia dwie instytucje odpowiedzialne za bieżącą współpracę z Wietnamem: Kierowniczą Grupę ds. Stosunków z Wietnamem oraz Grupę Wsparcia dla Wietnamu, podległą Komitetowi Centralnemu i Radzie Państwowej (rządowi), składającą się z przedstawicieli różnych ministerstw oraz wyższych oficerów wydziałów Sztabu Generalnego ChALW ${ }^{24}$. W przeciwieństwie do pierwszej wojny indochińskiej, kiedy chińscy doradcy polityczni i wojskowi byli bezpośrednio zaangażowani w prowadzenie działań wojennych, w latach 60. XX w. Wietnamczycy nie dopuszczali ich do udziału w podejmowaniu decyzji strategicznych. Wietnam Północny dysponował już niezależnym i o wiele sprawniejszym aparatem działania niż Viet Minh w latach 50. XX w. Przeprowadzano regularne konsultacje i informowano na bieżąco o rozwoju sytuacji. Pekin i Hanoi zdawały się osiągnąc porozumienie co do podziału kompetencji: Wietnamczycy mieli prowadzić wojnę własnymi siłami, podczas gdy Chińczycy mieli ich wspierać logistycznie i materiałowo na Północy ${ }^{25}$. Osiągnięto też konsesus w sprawie militarnego zaangażowania ChALW w Wietnamie: jeśli oddziały

${ }^{23}$ Ibidem.

${ }^{24}$ Ibidem.

25 Jak się później okazało, Chińczycy mieli rozkaz nie używać swojej artylerii przeciwlotniczej poniżej 21. równoleżnika. 
amerykańskiej piechoty nie zaatakują Północy, co wiązałoby się z bezpośrednim zagrożeniem suwerenności ChRL, oddziały chińskie nie zostaną włączone do walki.

\section{Mocarstwowa gra sił i międzynarodowy charakter konflikłu}

Analizując stosunki wietnamsko-chińskie na tle wojny ze Stanami Zjednoczonymi, należy podkreślić międzynarodowy charakter konfliktu. Zasadniczym celem amerykańskiej administracji było zmuszenie DRW i Vietcongu do zaprzestania działań zbrojnych na terytorium Republiki Wietnamu. Prezydent Johnson prowadził wojnę ograniczoną i początkowo chciał uzyskać jak największe korzyści, nie angażując regularnych oddziałów US Army. Pierwszoplanową rolę w tej taktyce odgrywało wykorzystanie lotnictwa do nalotów na terytorium Wietnamu Północnego $^{26}$. Świadomy amerykańskich celów rząd DRW zajmował twarde stanowisko w stosunku do podjęcia negocjacji, wiedząc, że wraz z upływem czasu i bez wymiernych sukcesów administracja prezydenta Johnsona będzie się znajdowała pod coraz większą presją ze strony opinii publicznej.

Przez większą część wojny indochińskiej głównym wrogiem Stanów Zjednoczonych były komunistyczne Chiny. Dla Mao Zedonga wspieranie DRW i walka z imperialistycznym mocarstwem stanowiła szansę umocnienia przywództwa Chin pośród ruchów narodowowyzwoleńczych Azji i mogła być doskonale wykorzystana propagandowo ${ }^{27}$. Atmosfera towarzysząca zaangażowaniu ChRL w konflikt służyła ponadto Mao do prowadzenia walki politycznej w kraju. Wpływ tego czynnika objawił się z całą mocą na przełomie lat 60. i 70. XX w., kiedy potrzeba wewnętrznej stabilizacji zmusiła rząd ChRL do przewartościowania swoich planów pomocy dla Wietnamu. Ważnym elementem wpływającym na chińską politykę w okresie drugiej wojny indochińskiej była rywalizacja z ZSRR ${ }^{28}$. W końcu lat

268 i 9 kwietnia 1965 r. samoloty amerykańskie naruszyły chińską przestrzeń powietrzną nad wyspą Hainan. Z inicjatywy Mao wydano rozkaz, zgodnie z którym chińskie siły powietrzne miały atakować jednostki amerykańskie, jeśli te naruszyły terytorium ChRL. Jak podaje Chen Jian, do listopada 1968 r. lotnictwo chińskie brało udział w 155 operacjach spowodowanych naruszeniem przestrzeni powietrznej ChRL. Chen Jian, op.cit.

${ }^{27}$ W kwietniu 1965 r. odbyło się spotkanie przywódców państw niezaangażowanych Azji, reprezentowanych przez Zhou Enlaia, króla Kambodży Norodoma Sihanouka, króla Laosu Souphanouvonga, przywódcę Korei Północnej Kim Ir Sena oraz Pham Van Donga. Wobec nieobecności przedstawicieli ZSRR delegacja chińska doskonale wykorzystała okazję do zacieśnienia ,antyimperialistycznej solidarności krajów niezaangażowanych" i poparcia walki narodowowyzwoleńczej, czego przykładem miał być sojusz z DRW.

${ }_{28}$ Począwszy od 1965 r., pomoc ZSRR dla Wietnamu systematycznie rosła. W latach 1965-1968 DRW otrzymała pomoc militarną o wartości 1,8 mld USD oraz miliard USD ramach pomocy gospodarczej. Wartość pomocy radzieckiej przewyższała wartość chińskiego zaangażowania, które jednak 
60. XX w. ZSRR stał się dla ChRL wrogiem numer jeden, co skłaniało kierownictwo KPCh do zmiany nastawienia wobec polityki Stanów Zjednoczonych i przyjęcia łagodniejszego kursu wobec wojny wietnamskiej.

Kolejnym czynnikiem wpływającym na umiędzynarodowienie konfliktu była kwestia Laosu i Kambodży, które Wietnam tradycyjnie traktował jako swoją strefę wpływów. Terytorium Laosu, przez które przebiegał główny wietnamski szlak przerzutowy, było narażone od początku wojny na bombardowania amerykańskie. Król Kambodży Norodom Sihanouk po zerwaniu stosunków z USA zwrócił się o pomoc do Chin, które mogły wpłynąć na zmniejszenie skali penetracji terytorium Kambodży przez armię Vietcongu ${ }^{29}$. Wizyta Sihanouka w Pekinie we wrześniu 1965 r. była istotnym wydarzeniem dla obu stron oraz dla całej perspektywy rozwoju sytuacji w Indochinach. Nawiązawszy bliższą współpracę, Chiny skłoniły Sihanouka do akceptacji wietnamskich „sanktuariów” na terenie Kambodży i przemytu broni przez port Kompong Som. W ten sposób Chińczycy, pomagając Vietcongowi, uzyskali większy wpływ na rozwój wydarzeń w Kambodży.

\section{Znaczenie chińskiej pomocy dla walki o zjednoczenie Wietnamu}

Z roku na rok rosła liczba amerykańskich nalotów i bombardowań Północy i Południa. W 1965 r. zrzucono na terytorium DRW 63 tys. ton bomb, podczas gdy w 1967 r. już 226 tys. ton ${ }^{30}$. Celem bombardowań na Południu były bazy Vietcongu, a na Północy głównie obiekty infrastruktury i bazy militarne, jak i szlaki komunikacyjne w obu częściach kraju. W 1967 r. lotnictwo amerykańskie rozpoczęło regularne naloty na bazy Vietcongu na terytorium południowego Laosu, a od 1969 r. również Kambodży. Odbudowa zniszczeń i sprostanie amerykańskiej presji militarnej opierały się w dużym stopniu na pomocy z ChRL i ZSRR.

Zaangażowanie chińskie w pomoc DRW w okresie 1965-1969 szło w trzech głównych kierunkach: wkład chińskich wojsk inżynieryjno-saperskich w budowę i utrzymanie konstrukcji obronnych, lotnisk, dróg i linii kolejowych w Wietnamie Północnym; wykorzystanie chińskich jednostek obrony przeciwlotniczej do ochrony ważnych strategicznie obiektów i obszarów na północy DRW; dostawy dużych ilości sprzętu wojskowego oraz materiałów wyposażenia i zaopatrzenia dla żołnie-

miało swój specyficzny i poniekąd niewymierny charakter wynikający ze znajomości wietnamskich realiów. Należy też pamiętać, że ChRL przez większość wojny stanowiła bezpośrednią zaporę dla Amerykanów, którzy musieli się liczyć z możliwością bezpośredniej reakcji Chin w obliczu dalszej eskalacji wojny, szczególnie na terytorium DRW.

29 Piotr Ostaszewski, op.cit., s. 418.

30 Ibidem, s. 425. 
rzy i cywilów ${ }^{31}$. Pierwsze brygady chińskich inżynierów zostały wysłane do Wietnamu Północnego wiosną 1965 r. Uczestniczyły w realizacji 100 projektów, m.in. w przebudowie linii kolejowych Hanoi-Youyiguan i Hanoi-Thai Nguyen. Były zorganizowane w strukturę nazwaną Chińskie Ludowe Ochotnicze Siły Inżynieryjne (Chinese People's Volunteer Engineering Force - CPVEF) ${ }^{32}$. Kolejnym ważnym obszarem objętym chińską pomocą było wykorzystanie chińskich oddziałów obrony przeciwlotniczej, osłaniających wybrane cele na północy DRW i zapewniających bezpieczeństwo CPVEF $^{33}$. Nasilenie chińskich dostaw dla wojska i cywilów znacznie wzrosło wraz z wysłaniem chińskich ochotników do budowy infrastruktury.

Mimo, że Pekin miał swoje powody do udzielenia wsparcia południowym sąsiadom, które bynajmniej nie sprowadzały się do deklarowanej internacjonalistycznej misji pomocy walczacemu narodowi wietnamskiemu, to wkład chiński w subsydiowanie i pomoc logistyczną DRW trudno przecenić. W sumie 320 tys. chińskich żołnierzy było zaangażowanych w prace konstrukcyjne na północ od 21. równoleżnika. Zapotrzebowanie Hanoi było większe i nie wszystkie prośby o wsparcie zostały przez Chińczyków spełnione. Jednocześnie DRW obawiała się też zbytniego nasilenia pomocy, wiedząc, że Chińczycy realizują w Wietnamie własne cele polityczne. Symptomatyczne wydaje się, że wraz z rozlokowaniem pierwszych dywizji CPVEF zaczęły się tarcia i nieporozumienia we wzajemnych kontaktach. Wkład ChALW w wojnę wietnamską pomógł DRW przetrwać amerykańską presję pierwszych lat wojny i rozwinąć infrastrukturę potrzebną do sprawnego działania machiny wojennej. Rząd DRW mógł skoncentrować się w większym stopniu na Południu, absorbując w ten sposób US Army na jej terenie. Celem, któremu bezwzględnie podporządkowana była polityka DRW, było wygranie wojny i zjednoczenie kraju.

Polityka ChRL w Wietnamie wiązała się z rozwojem sytuacji wewnętrznej w kraju, gdzie trwała pierwsza, najburzliwsza faza „rewolucji kulturalnej” wraz $\mathrm{z}$ dążeniem do wzniecenia rewolucji w innych państwach regionu ${ }^{34}$. Towarzyszyła temu również silna obawa przed zaangażowaniem ZSRR w Indochinach. Wraz $\mathrm{z}$ rozpoczęciem przez CPVEF misji w Wietnamie pojawiły się trudności związa-

${ }^{31}$ ChRL dostarczała do Wietnamu głównie broń, pociski i sprzęt artyleryjski. Szczytem nasilenia chińskich dostaw był 1968 r., kiedy dostarczono niespełna 220 tys. sztuk broni, ok. $250 \mathrm{mln}$ pocisków różnego kalibru, ponad 7 tys. wyrzutni artyleryjskich. Następnie pomoc chińska zaczęła maleć, osiągając najniższy poziom w 1970 r. i ponownie nasilając się w latach 1972-1973. Analogiczna tendencja dotyczy zaopatrzenia dla łączności, tj. radioodbiorników, telefonów, telegrafów.

32 Szerzej patrz: Chen Jian, op.cit., s. 356-387.

33 Ibidem.

34 Szerzej na temat uwarunkowań sytuacji wewnętrznej Chin tego okresu patrz: John King Fairbank, Historia Chin. Nowe spojrzenie, Warszawa-Gdańsk 2003. 
ne z blokowaniem chińskich inicjatyw przez władze lokalne DRW. W odpowiedzi Mao Zedong polecił nie okazywać nadmiernego entuzjazmu w oferowaniu pomocy Wietnamczykom. Problemy we wzajemnych stosunkach były omawiane na spotkaniu delegacji wietnamskiej pod przewodnictwem Le Duana z delegacją chińską pod kierownictwem Zhou Enlaia i Deng Xiaopinga 13 kwietnia 1966 r. w Pekinie. Choć strona wietnamska przyznała, że wynikłe problemy miały charakter odosobniony i nie wpływały na przyjazny i sojuszniczy stosunek DRW do ChRL, to dało się wyczuć wyraźne ochłodzenie nastrojów. Strona chińska zarzucała Wietnamczykom, że pomoc ChRL traktują jako swoistą ekspansję, czemu Le Duan zaprzeczał. Zhou Enlai dodawał, że rozumie przychylne stanowisko Wietnamu wobec Związku Radzieckiego, ale nie życzy sobie, aby wymieniać ChRL obok ZSRR przy okazji okazywania wdzięczności za dostarczaną pomoc ${ }^{35}$. Podczas swojego przemówienia na XXIII Zjeździe KPZR w Moskwie Le Duan określił Związek Radziecki mianem „drugiej ojczyzny”, co wprawiło chińskich przywódców we wściekłość. W kilka miesięcy później, kiedy rząd DRW zwrócił się do ChRL z prośbą o przedłużenie pobytu drugiej dywizji CPVEF, spotkał się z odmową.

Na początku 1966 r. miał miejsce incydent związany z przetrzymaniem przez 4 dni na redzie w Haifongu chińskiego statku „Hongqi”, transportującego materiały dla DRW. Powagi sytuacji dodawał fakt, że w tym czasie został on poważnie uszkodzony w wyniku nalotów amerykańskich, podczas gdy wpuszczono statek radziecki przybyły w późniejszym terminie. Sprawa ta była wyjaśniana podczas kwietniowej wizyty Le Duana w Pekinie, ale nie pozostała bez echa. Mimo zabiegów dyplomacji północnowietnamskiej rozłam pogłębiał się w miarę nasilania radzieckiej pomocy dla DRW i Vietcongu.

Chcąc utrzymać dwa równorzędne źródła zaopatrzenia, rząd DRW umiejętnie rozgrywał swoją kartę. Zdając sobie sprawę z wagi, jaką KPCh przywiązywała do wojny wietnamskiej, starał się mobilizować Chińczyków do zwiększania dostaw, podkreślając duże zaangażowanie radzieckie. Jednakże z czasem wietnamska polityka jednakowego traktowania ChRL i ZSRR stała się dla KPCh nie do przyjęcia.

Mao obawiał się, że Związek Radziecki sprzymierzy się z USA przeciwko Chinom i wstrzyma rewolucje w krajach Azji Południowo-Wschodniej - stąd wrogi stosunek do popieranych przez Moskwę wietnamsko-amerykańskich rokowań pokojowych. Dla odparcia wpływów radzieckich i zrealizowania planu wzniecenia rewolucji na całym Półwyspie Indochińskim (a docelowo we wszystkich państwach Trzeciego Świata) niezbędny był Chinom wpływ na tamtejsze partie komunistycz-

${ }^{35}$ Spotkanie Zhou Enlaia, Deng Xiaopinga, Kang Shenga z Le Duanem, Nguyenem Duy Trinh w Pekinie, 13 kwietnia 1966; Cold War International History Project, Woodrow Wilson International Center for Scholars, http://wwics.si.edu/index.cfm?topic_id=1409\&fuseaction=library. document\&id=140 (wejście: 21.01 .2005 ). 
ne. Mao był szczególnie zainteresowany rewolucją w Tajlandii, na terytorium której były rozlokowane amerykańskie bazy militarne. W rozmowach z przedstawicielami Laotańskiej Partii Ludowej (LPL) twierdził, że skoro Amerykanie używają baz w Tajlandii do organizowania nalotów na wyzwolone obszary Laosu, to LPL ma pełne prawo zaatakować Tajlandię i pomóc tamtejszej partii komunistycznej „wzniecić płomień rewolucji”.

Równie ważne miejsce w planach przewodniczącego Mao zajmowała Birma, gdzie w 1967 r. doszło do antychińskich wystąpień. Komunistyczna Partia Birmy była subsydiowana przez ChRL, a jej kadry przechodziły szkolenia w obozach na terytorium Yunnanu i Guangxi (część z nich znajdowała tam schronienie na długie lata). Zamieszkujące regiony przygraniczne mniejszości narodowe były instrumentalnie wykorzystywane przez władze chińskie do prowokowania incydentów antyrządowych. Na granicy dochodziło nawet do starć armii chińskiej z birmańskimi siłami rządowymi ${ }^{36}$.

Tymczasem nieskuteczność amerykańskiej taktyki (brak wymiernych sukcesów mimo eskalacji działań i brutalizacji wojny) była dla ChRL dobrym sygnałem. Jednocześnie silna pozycja Wietnamczyków w państwach sąsiednich potęgowała napięcia chińsko-wietnamskie. Wciąż jednak Ho Chi Minh szukał w ChRL rad i wsparcia w działaniach zmierzających do zjednoczenia kraju, a przywódcy chińscy darzyli wietnamskich „towarzyszy broni”, a w szczególności bojowników Vietcongu, głęboką estymą ${ }^{37}$. Specjalne miejsce DRW w polityce ChRL wiązało się ze specyficznym charakterem chińskiej pomocy, w której dużą rolę odgrywało wsparcie logistyczne i koncepcyjne, a nie tylko pomoc materiałowa. Ponadto, choć perspektywa ukształtowania na wzór chiński przyszłej niepodległości Wietnamu oddalała się, ChRL wciąż miała żywotne interesy w Wietnamie. W kwietniu 1967 r. chińscy i wietnamscy przywódcy wyrazili przypuszczenie, że 1968 r. będzie przełomowy i Vietcong pokona Amerykanów podczas pory suchej. W czasie pobytu na leczeniu w Pekinie Ho Chi Minh spotkał się z Mao Zedongiem, który namawiał go do przejścia od walki partyzanckiej do wielkiej ofensywy na Południu.

W kwietniu 1967 r. na XIV Plenum KC PPW podjęto decyzję o przeprowadzeniu z początkiem 1968 r. wielkiej ofensywy. Nie jest jasne, w jakim stopniu rady przywódców chińskich przyczyniły się do jej podjęcia, natomiast faktem jest, że kluczowe było dostosowanie taktyki walki rewolucyjno-niepodległościowej do wietnamskich realiów, zgodnie z postulatem gen. Vo Nguyen Giapa, przedstawio-

${ }^{36}$ Polityka wykorzystywania mniejszości etnicznych, w tym licznej we wszystkich państwach indochińskich mniejszości chińskiej, była jednym z elementów presji, jaką ChRL starała się wywierać dla promowania rewolucji w regionie.

37 Xiaoming Zhang, The Vietnam War, 1964-1969: A Chinese Perspective, „The Journal of Military History", October 1996, No. 4, s. 731-762. 
nym na XII Plenum KC PPW w styczniu 1966 r. W sensie militarnym ofensywa ta okazała się porażką komunistów. Oczekiwana rewolucja w miastach Wietnamu Południowego i na prowincji w ogóle nie doszła do skutku. Amerykańska kontrofensywa zdziesiątkowała wojska Vietcongu i doprowadzona do końca mogłaby poważnie zagrozić pozycjom armii północnowietnamskiej.

Rok 1968 był przełomowy dla wojny wietnamskiej. W maju przedstawiciele DRW przystąpili do wstępnych rokowań pokojowych w Paryżu, prowadzonych przez nową ekipę amerykańską prezydenta Richarda Nixona. Przywódcy chińscy uważali jednak, że DRW zbyt szybko i pochopnie przystąpiła do negocjacji, nie odniósłszy znacznego zwycięstwa na polu walki. W rozmowie z delegacją wietnamską 7 maja Zhou Enlai przestrzegał także przed ujawnianiem Rosjanom swojego pełnego stanowiska negocjacyjnego, sugerując, że mogliby oni przekazać informacje stronie amerykańskiej. W tym samym czasie przebywające w Wietnamie jednostki CPVEF rozpoczęły wycofywanie z terytorium DRW.

\section{Nowy kurs w polityce zagranicznej ChRL. Osłabienie sojuszu chińsko- -wietnamskiego. ChRL wobec zjednoczenia Wietnamu}

W końcu 1968 r. Mao Zedong i Zhou Enlai zaczęli rozważać rolę Stanów Zjednoczonych w zapewnieniu ChRL zadania priorytetowego - bezpieczeństwa ${ }^{38}$. Duża część napięć między Pekinem i Hanoi dotyczyła kwestii negocjacji ze Stanami Zjednoczonymi. Kiedy ChRL zaczęła szukać zbliżenia z USA, krytycyzm Mao wobec polityki DRW zaczął słabnąć. Jednocześnie nie było już bezpośredniej motywacji do utrzymania wysokiego poziomu chińskiej pomocy dla DRW. Pekin co prawda odpowiedział pozytywnie na prośbę Hanoi o zwiększenie pomocy wojskowej wobec kolejnej fali bombardowań amerykańskich w maju 1972 r., ale generalna tendencja pozostała malejąca.

Mimo bliskich kontaktów przywódców ChRL i DRW Chińczycy byli świadomi faktu, że ich wpływ na politykę Hanoi został ograniczony. Rozdźwięk między retoryką Mao o wspieraniu rewolucji na świecie a zbliżeniem ChRL z USA był negatywnie odbierany w DRW i potwierdzał wcześniejsze obawy Wietnamczyków, jakoby Pekin rozgrywał w Wietnamie jedynie swoją własną kartę. Przywódcy chińscy zaczęli w tajnych rozmowach z Wietnamczykami zajmować przychylne stanowisko wobec rokowań paryskich, jednocześnie nie odżegnując się od retoryki namawiającej do walki z imperializmem. W rozmowie z Nguyen Thi Binhem, ministrem spraw zagranicznych Tymczasowego Rządu Rewolucyjnego Republiki

${ }^{38}$ Dotychczasowa strategia walki na dwa fronty z największymi mocarstwami była samobójcza dla Chin. 
Wietnamu Południowego (TRRRWP), 29 grudnia 1972 r. w Pekinie przewodniczący Mao sugerował, że jeśli rokowania paryskie osiągną pożądany skutek, DRW będzie mogła stopniowo normalizować swoje stosunki z USA ${ }^{39}$. Przyznał jednocześnie, że w 1968 r. popełnił błąd, sprzeciwiając się podjęciu rozmów pokojowych.

Redukcji amerykańskiego kontyngentu w Wietnamie towarzyszyła eskalacja wojny w Kambodży, gdzie 17 marca 1970 r. w wyniku zamachu stanu władzę przejął prawicowy generał Lon Nol, który natychmiast uwikłał kraj w konfrontację z Vietcongiem i związał się z chętnymi do udzielenia pomocy Republiką Wietnamu i USA. Zaistniała sytuacja zaktywizowała dyplomację chińską, która udzieliła poparcia emigracyjnemu rządowi księcia Norodoma Sihanouka i Czerwonych Khmerów. Wojna w Kambodży otworzyła drogę do władzy wspieranym przez DRW i ChRL Czerwonym Khmerom.

Naloty lotnictwa USA na terytorium Laosu w 1971 r. oznaczały dalszą eskalację konfliktu. Nieudana w 1972 r. ofensywa wielkanocna sił DRW i Vietcongu, która upewniła Amerykanów, że administracja prezydenta Nguyen Van Thieu jest w stanie sprawować władzę i bronić kraj, przyspieszyła podpisanie 27 stycznia 1973 r. tzw. traktatów paryskich oraz zawieszenia broni.

Podpisanie traktatów paryskich było sukcesem DRW, którą uznano za stronę w konflikcie, a nie agresora. Porozumienia legitymizowały TRRRWP, nadając mu równorzędny status z rządem w Sajgonie. Trójstronna Rada Porozumienia Narodowego miała natomiast jedynie status ciała administracyjnego. W zaistniałej sytuacji prezydent Nguyen Van Thieu musiał sabotować próby powołania wspólnego rządu, aby utrzymać władzę w Wietnamie Południowym. Z kolei rząd DRW powoływał się na postanowienia traktatów paryskich dla realizacji swoich planów zjednoczeniowych.

Sukces DRW miał też ogromny efekt propagandowy, który chciały wykorzystać obydwa mocarstwa komunistyczne: ChRL i ZSRR. W 1973 r. odnotowano ponowny wzrost dostaw broni i pocisków artyleryjskich z Chin do Wietnamu ${ }^{40}$. Podczas spotkania delegacji wietnamskiej z premierem Zhou Enlaiem 6 czerwca tegoż roku w Pekinie omawiano strategię działania na najbliższe lata. Obie strony zgadzały się co do potrzeby zjednoczenia $\mathrm{w}$ dalszej perspektywie. Zhou podkreślał ciągłe zagrożenie przez Stany Zjednoczone i postulował przyjęcie taktyki pokojowego współistnienia dla rozwoju gospodarczego przed ewentualną przyszłą konfronta$\mathrm{cją}^{41}$. Chinom zależało na jednoczesnym stworzeniu wizerunku orędownika poko-

39 Spotkanie przebiegało podczas ciężkich tzw. świątecznych bombardowań Hanoi i Hajfongu przez lotnictwo USA.

${ }^{40}$ Chen Jian, op.cit.

${ }^{41}$ Zhou Enlai and Le Duan, Pham Van Dong and Le Thanh Nghi; Beijing, 6 June 1973. Cold War International History Project, Woodrow Wilson International Center for Scholars, http://wwics. si.edu/index.cfm?topic_id=1409\&fuseaction=library.document\&id=61(wejście: 22.03 .2005 ). W rozmowie z Pham Van Dongiem 16 sierpnia 1973 r. Zhou Enlai akcentował również potrzebę elastycz- 
ju w regionie i poplecznika zwycięskiej DRW. Wietnam Północny potrzebował natomiast chińskiej pomocy wobec możliwości konfrontacji z reżimem sajgońskim.

Mimo to w stosunku władz wietnamskich do Pekinu nie malały rezerwa i podejrzliwośćc ${ }^{2}$, na co miała również wpływ pamiętna wizyta Nixona w Pekinie w 1972 r. Kolejnym obszarem narastającego antagonizmu była kwestia wpływów w Kambodży, gdzie działała silna infrastruktura Vietcongu, oraz w kambodżańskim ruchu komunistycznym, któremu zaplecza udzielała ChRL. Wobec wycofania się wojsk amerykańskich z Kambodży, Laosu i Wietnamu i przejścia USA do polityki pomocy ekonomicznej proamerykański rząd Souvanna Phoumy i Republika Khmerska Lon Nola znalazły się w defensywie ${ }^{43}$.

Mimo napięć w stosunkach Hanoi z Pekinem i pozostawiających też wiele do życzenia relacji z Moskwą DRW znajdowała się w dużo korzystniejszej sytuacji niż Republika Wietnamu. Mając znaczne obszary pod swoją kontrolą za pośrednictwem sojuszniczego TRRRWP, rząd w Hanoi rozpoczął działania na rzecz utworzenia gabinetu koalicyjnego, zgodnie z postanowieniami porozumień paryskich. Nie liczono wszakże na zjednoczenie na drodze dyplomatycznej i odstąpienie Nguyena Van Thieu od pełni władzy na Południu. Jednakże przyjęcie pokojowej strategii (prób implementacji postanowień paryskich w połączeniu z działalnością agitacyjną w Republice Wietnamu) było korzystne propagandowo, oddalało perspektywę ewentualnej interwencji amerykańskiej i dawało chwilę wytchnienia wyniszczonej gospodarce $\mathrm{kraju}^{44}$.

Stosunek Chińczyków do wydarzeń na Południu pozostawał ostrożny. Nie jest zapewne prawdą, co podkreślały źródła wietnamskie w okresie późniejszym, jakoby ChRL występowała przeciw zjednoczeniu Wietnamu. Rząd Chin, kierując się potrzebą zapewnienia bezpieczeństwa międzynarodowego, akcentował raczej prawo do samostanowienia Wietnamczyków z Południa i walki z neokolonializmem niż zaadaptowania tam ustroju komunistycznego. Jednocześnie w rozmowach dwustronnych z przedstawicielami DRW podkreślano dobrą wolę i wieloletnią pomoc.

\footnotetext{
nego podejścia do wrogich państw, aby móc wygrać nieprzyjaciół przeciw sobie. Nawiązywał w ten sposób do koncyliacyjnego stanowiska wobec USA i powagi zagrożenia ze strony Moskwy, http:// wwics.si.edu/index.cfm?topic_id=1409\&fuseaction=library.document\&id=175 (wejście: 22.03 .2005 ).

${ }^{42}$ Strona chińska skarżyła się na obraz Chin w wietnamskiej prasie, która wielokrotnie wskazywała na groźbę inwazji z Północy.

43 Podpisane 21 lutego 1973 r. porozumienia dotyczące Laosu zakładały całkowitą neutralizację, wycofanie obcych wojsk, powołanie rządu koalicyjnego i rozpisanie wolnych wyborów.

${ }^{44}$ Kontynuowanie ofensywy zbrojnej przeczyłoby też podkreślanej przez Hanoi tezie, że społeczeństwo południowowietnamskie oczekuje wyzwolenia i zjednoczenia kraju pod egidą DRW.
} 
Z początkiem 1974 r. prezydent Nguyena Van Thieu ogłosił wznowienie walk w Wietnamie ${ }^{45}$. Szybkie tempo postępów ofensywy Vietcongu paraliżowało jakąkolwiek reakcję administracji USA, niemającej zresztą wsparcia Kongresu. 30 kwietnia 1975 r. został zdobyty Sajgon, który przemianowano na miasto Ho Chi Minha. Równolegle z upadkiem Republiki Wietnamu nastąpiło zdobycie władzy przez Czerwonych Khmerów w Kambodży. Zjednoczenie Wietnamu zostało przypieczętowane 2 lipca 1976 r. proklamowaniem Socjalistycznej Republiki Wietnam ze stolicą w Hanoi.

\section{Perspektywa wzajemnych relacii po wojnie. Kolejne obszary napięć}

Pomoc chińską dla Wietnamu z okresu pierwszej i drugiej wojny indochińskiej szacuje się na ok. 20 mld USD ${ }^{46}$. Silny w relacjach wietnamsko-chińskich czynnik ideologiczny umożliwiał efektywne prowadzenie w stosunkach dwustronnych real politik, służącej bezpośrednio interesom państwowym ${ }^{47}$. Chińska presja na odrzucenie ,międzynarodowego hegemonizmu” jako synonimu polityki ZSRR wynikała $\mathrm{z}$ chęci odsunięcia wroga $\mathrm{w}$ tak istotnym strategicznie dla Chin kraju, jak Wietnam. Ostrożność Hanoi wobec bliskiej współpracy z Pekinem i polityka równoważenia pomocy chińskiej dostawami radzieckimi stała się permanentnym problemem we wzajemnych relacjach. Bardzo źle przyjęte przez wietnamską opinię publiczną nawiązanie dialogu amerykańsko-chińskiego zaowocowało wzrostem antychińskich nastrojów i przyczyniło się do zacieśnienia współpracy DRW z ZSRR. Ochłodzenie tuszowane było przez spotkania na najwyższym szczeblu i podkreślanie współpracy obu państw (głównie chińskiej pomocy).

W latach 70. XX w. między socjalistycznymi sąsiadami narastały nowe problemy. Jednym z nich była delimitacja granicy chińsko-wietnamskiej w Zatoce Tonkińskiej. Rząd DRW chciał rozpocząć eksploatację tego obszaru jako część odbudowy gospodarczej kraju. Strona chińska zaproponowała podział wód Zatoki, tak aby żadne trzecie państwo nie mogło być dopuszczone do korzystania z nich. Jednakże rozmowy prowadzone jesienią $1974 \mathrm{r}$. nie przyniosły rozstrzygnięcia ${ }^{48}$. Na

${ }^{45}$ Faktycznie rozpoczęcie trzeciej wojny indochińskiej nastąpiło już w 1973 r., kiedy w odpowiedzi na wojnę zaczepną Vietcongu armia Republiki Wietnamu przystąpiła do akcji „oczyszczania" obszarów zajętych przez wroga w delcie Mekongu.

46 Dla porównania, pomoc radziecka z okresu drugiej wojny indochińskiej wyniosła $7088 \mathrm{mln}$ USD. Piotr Ostaszewski, op.cit., s. 550.

${ }^{47}$ Carlyle A. Thayer, Sino-Vietnamese Relations: The Interplay of Ideology and National Interest, „Asian Survey” 1994, Vol. 34, No. 6, s. 513-528.

${ }^{48}$ Ministry of Foreign Affairs, Socialist Republic of Vietnam, The Truth about Vietnam-China Relations over the Past Thirty Years, Hanoi 1979. 
początku roku chińskie wojska zajęły część archipelagu Paraceli, pozostającą do tamtego czasu pod kontrolą reżimu sajgońskiego. Ponieważ zarówno Wietnam, jak i Chiny rościły sobie prawa do zwierzchnictwa nad wyspami, wicepremier Deng Xiaoping przyznał, że konieczne było podjęcie negocjacji, by rozstrzygnąć problem $^{49}$. Spór nie został jednak rozwiązany, a kwestia wytyczenia granicy i praw do eksploatowania zasobów Morza Południowochińskiego wciąż rzuca cień na wzajemne stosunki.

Kolejnym obszarem konfliktu po zjednoczeniu Wietnamu stała się kwestia stosunków między Wietnamem, Kambodżą, Laosem i chińskiego zaangażowania w te relacje. Obecność armii Vietcongu na obszarach sąsiednich państw indochińskich doprowadziła do napięć szczególnie w kontaktach z nowo ukonstytuowanym reżimem Czerwonych Khmerów. Rosnąca wrogość na linii Phnom Penh-Hanoi wyrażała i jednocześnie potęgowała spór o przywództwo między Wietnamem a ChRL. Chińczycy starali się rozgrywać swoją kartę, wspierając rząd Pol Pota i Ienga Sary. Dodatkowym czynnikiem, który komplikował sytuację polityczną w regionie, były problemy związane z mniejszościami narodowymi (chińską w Wietnamie, wietnamską w Kambodży i Laosie) i wykorzystanie ich w rozgrywce politycznej, co potęgowało wzajemne poczucie zagrożenia. Na fali rosnących napięć coraz bardziej zmieniał się obraz Wietnamu w chińskiej opinii publicznej, przechodząc od pierwszego państwa na froncie walki z międzynarodowym imperializmem do propagatora (radzieckiego) hegemonizmu i „Kuby Wschodu”. Kulminacją napięć między SRW i ChRL i ich rywalizacji o prymat na Półwyspie Indochińskim stał się w 1979 r. krótkotrwały konflikt zbrojny.

Stosunek rządu ChRL wobec nowo powstałej Demokratycznej Republiki Wietnamu determinowała wspólnota interesów, a szczególnie wizja wspólnego wroga, którym były Stany Zjednoczone. Dla Wietnamczyków z Północy walka z Amerykanami była stałym paradygmatem polityki zagranicznej i zmaterializowała się w okrutnym i wyniszczającym konflikcie prowadzonym na terytorium kraju. Dla Chin relacja ze Stanami Zjednoczonymi stopniowo otwierała więcej możliwości niż tylko rywalizacja przez wspieranie walki w Wietnamie. Spadek chińskiego zaangażowania w wojnę na Południu popychał kierownictwo DRW w kierunku równoważenia sojuszu przez zbliżenie ze Związkiem Radzieckim. Oczywiście wyjątkowości relacji Chin wobec Wietnamu, opartej na wielowiekowej wspólnocie dziedzictwa kulturalnego i historycznego, nie można sprowadzić do funkcji zbli-

49 Po zajęciu całego archipelagu strona chińska uznała go za historycznie integralną część terytorium Chin i odmówiła jakichkolwiek negocjacji w tej kwestii. 
żenia lub konfrontacji w stosunkach z USA oraz cyklicznej potrzeby stabilizacji wewnętrznej w Chinach. „Sprawa wietnamska” znajdowała duże poparcie w społeczeństwie chińskim. Warto też przypomnieć, że w kierownictwie KPCh istniały podziały co do stopnia i sposobu zaangażowania w wojnę wietnamską. Kontakty na szczeblu rządowym opierały się również na osobistym stosunku wielu chińskich i wietnamskich przywódców, a erozja sojuszu i narastające napięcia tylko unaoczniły stopień zbliżenia i rozczarowania po obu stronach.

Powyższa analiza stanowi więc jedynie próbę uchwycenia momentu historycznego przez pryzmat współrzędnych, które determinowały interesy polityczne rządów obu państw w okresie od ogłoszenia niepodległości Demokratycznej Republiki Wietnamu do zjednoczenia kraju.

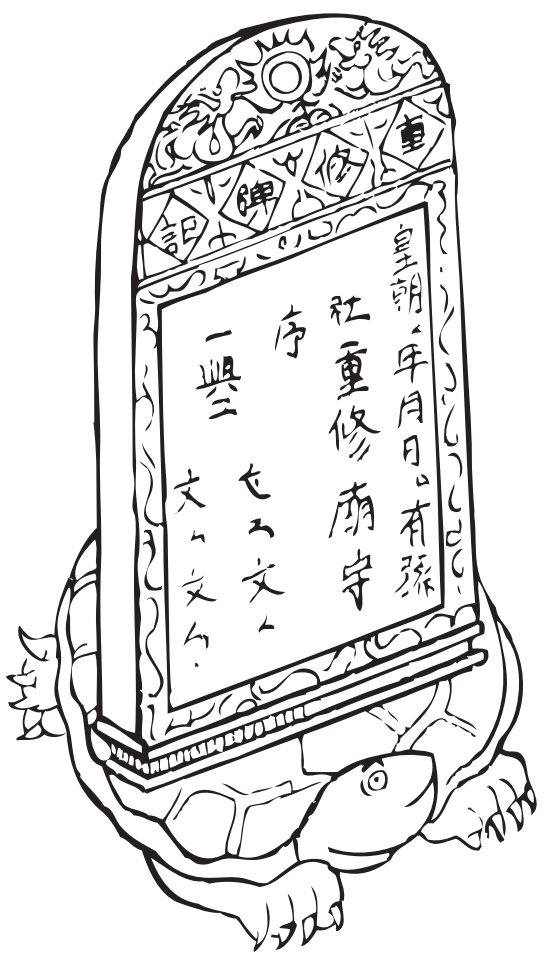

